\title{
USE OF CHLROPHYLL FLUORESCENCE SORTING TO IMPROVE SOYBEAN SEED QUALITY ${ }^{1}$
}

\author{
SILVIO MOURE CICERO2; ROB VAN DER SCHOOR 3 ; HENK JALINK³
}

\begin{abstract}
The occurrence of green seeded soybeans [Glycine max (L.) Merrill] is a problem closely related to unfavorable climatic conditions, mainly drought, that occurs during the final stages of seed maturation. This problem causes serious losses to soybean seed quality in Brazil. In these seeds, chlorophyll is not properly degraded during maturation, drastically reducing seed quality. Using the chlorophyll fluorescence technique, it is possible to remove green seeds from the seed lot, improving seed quality in several species in which the occurrence of green seeds is also a problem. The objective of this research was to study the use of the chlorophyll fluorescence technique in sorting green seeds from soybean seed samples and its effects on quality. Five seed samples of soybean, cultivar TMG 113 RR, with $0 \%, 5 \%, 10 \%, 15 \%$, and 20\% of green seeds were used in this study. Seeds from each sample were sorted into two fractions based on the chlorophyll fluorescence signals and then compared to the control (non-sorted seeds). The sorting process showed great differences between the low and high chlorophyll fluorescence fractions. It was concluded that: green seeds of soybeans present high chlorophyll fluorescence and that this characteristic affects the quality of the seeds; it is possible to improve the quality of soybean seed by removing green seeds using the chlorophyll fluorescence sorting technique.
\end{abstract}

Index terms: Glycine $\max ($ L.) Merrill, green seeds, seed maturation, seed processing, seed vigor.

\section{UTILIZAÇÃO DE FLUORESCÊNCIA DE CLOROFILA NA SEPARAÇÃO DE SEMENTES ESVERDEADAS DE SOJA}

\begin{abstract}
RESUMO - A ocorrência de sementes esverdeadas de soja [Glycine max (L.) Merrill] é um problema estreitamente relacionado a condições climáticas desfavoráveis, principalmente seca, que ocorrem nos estádios finais de maturação. Esse problema causa sérias perdas de qualidade da semente de soja no Brasil. Em sementes esverdeadas, a clorofila não é degradada adequadamente durante a fase final da maturação das sementes, afetando a sua qualidade. Com a técnica de fluorescência de clorofila, é possível remover sementes esverdeadas e melhorar a qualidade do lote de sementes de diversas espécies em que a ocorrência dessa característica também é um problema. Assim, a pesquisa teve o objetivo de estudar a utilização da técnica de fluorescência de clorofila na separação de sementes esverdeadas em amostras de sementes de soja e avaliar a sua relação com a qualidade. Cinco amostras de sementes de soja, cultivar TMG 113 RR, com $0 \%, 5 \%, 10 \%, 15 \%$ e $20 \%$ de sementes esverdeadas, foram utilizadas na pesquisa. As sementes de cada amostra foram separadas em duas frações baseadas nos sinais de fluorescência de clorofila e comparadas com a testemunha (amostra original, sem separação). O processo de separação proporcionou grande diferença entre as frações de baixa e de
\end{abstract}

${ }^{1}$ Subbmited on 02/04/2009. Accpeted for publication on 03/11/2009.

${ }^{2}$ University of São Paulo, Escola Superior de Agricultura “Luiz de Queiroz”, Crop Science Department, P.O. Box 9, 13418-900 Piracicaba, SP, Brazil; e-mail: smcicero@esalq.usp.br.

${ }^{3}$ Plant Research International, P.O. Box 16, 6700 AA Wageningen, The Netherlands. 
alta fluorescência de clorofila, permitindo concluir que: as sementes esverdeadas de soja apresentam alta fluorescência de clorofila e isto afeta a sua qualidade; é possível melhorar a qualidade do lote com a remoção de sementes esverdeadas, utilizando a técnica de separação por fluorescência de clorofila.

Termos para indexação: Glycine max (L.) Merrill, maturação de sementes, beneficiamento de sementes, vigor de sementes.

\section{INTRODUCTION}

In 2008/2009, soybean was cultivated in Brazil on $21,728,400$ ha, with a production of $57,088,100$ tons of grains (CONAB, 2009). Brazil is the second largest soybean producer in the world, with about $27 \%$ of the whole production.

The total amount of seed necessary to sow this area is of the order of 1,249,914 tons (ABRASEM, 2009). However, producing this amount of high quality soybean seed is a big challenge to seed producers, mainly because of unfavorable climatic conditions that frequently occur during the seed maturation period in tropical regions of Brazil, where over $60 \%$ of the soybean production concentrated. The occurrence of high levels of green seeds in the seed lots is becoming an increasingly important problem for the seed producers.

Under normal circumstances, during seed maturation, the enzyme chlorophyllase degrades the chlorophyll in soybean seeds. However, under dry and hot climatic conditions the seeds dry and mature faster than usual, ceasing the chlorophyllase enzyme activity before all the chlorophyll has been degraded (Bohner, 2003). Genotype and climatic conditions, especially temperature, are the most important factors that determine the frequency of green seeds occurring at harvest (McGregor, 1991).

The harmful effects of the occurrence of high temperatures during seed maturation are enhanced when in association with water deficit, resulting in large reductions in seed dry matter accumulation, seed number and seed size (Dornbos and Mullen, 1991). High temperatures promote very fast movement of the reserves, preventing complete chlorophyll degradation and resulting in the production of a high level of green seeds. Green seeds can also be caused by water shortage, by the application of desiccant herbicides at inappropriate moments (Marcos-Filho, 2005), by the application of incorrect doses of lime or fertilizers, this being a likely cause of irregular maturation, by root and leaves diseases, by insects attack, mostly stink-bugs, that favors leaf and green stem retention (França-Neto et al., 2005) and, also the application of some fungicides used to control of the Asian soybean rust (Zorato and Watanabe, 2006).

Green seeds occurrence has been pointed out as an important factor in quality loss of soybean seed lots. In lots with $100 \%$ of green seeds drastic reductions are reported in seed vigor compared to lots without the occurrence of green seeds, while in lots with $5 \%$ to $10 \%$ of green seeds the physiological quality of the seeds was little affected (Bohner, 2003). In the same way, in soybean seeds of the Conquista, BRS 138, CD 201 and EMGOPA 302 cultivars, with proportions of $0 \%, 10 \%, 20 \%, 30 \%$, and $100 \%$ of green seeds, it was verified that lots of all varieties with more than $10 \%$ of green seeds were inferior in physiological quality (Costa et al., 2001). Similar results were reported by Medina et al. (1997) and Pupim et al. (2005).

Soybean seed lots of the Tucunare and CD 206 cultivars showing between $0 \%$ and $100 \%$ of green seeds were reported by Padua et al. (2007) to have decreasing germination and vigor as the presence of green seeds increased. The author concluded that lots with green seed levels higher than $9 \%$ should not be used for sowing purposes.

Working with two soybean seed lots, Conquista cultivar, with $11.8 \%$ and $37.4 \%$ of green seeds, Zorato et al. (2007) verified that the green seeds presented low germination, lack of uniformity of developed seedlings, high deterioration rate, short seedling length, low 1000-seed weight and low seedling emergence in the field, regardless of the index of green seeds in the lots, although the worst results were observed with $37.4 \%$ of green seeds in the lot.

The removal of green seeds from soybean was studied by França-Neto et al. (2007), who worked with seed lots of the Conquista cultivar. They concluded that grading seeds according to size, using flat screen graders, was efficient to decrease the percentage of green seed in the seed lots; the highest percentage of green seeds (19\%) was found in the smallest seed (less than $6.0 \mathrm{~mm}$ ), compared to the large seed $(7.5 \mathrm{~mm})$, which had only $5 \%$ of green seeds. They verified that seed stratification favors high levels of green seed occurrence in the smallest fractions $(6$ and $6.5 \mathrm{~mm})$, 
which can be discarded as grain. Gravity tables were tested and found inefficient in separating green seed from the seed lots.

Chlorophyll fluorescence of the seed coat was proposed by Jalink et al. (1998) as a method for to determine seed maturity and quality. In that study, cabbage seeds (Brassica oleracea) were sorted into three sub-samples based on the chlorophyll fluorescence signals of the individual intact seeds. The results showed that seeds with the lowest amount of chlorophyll fluorescence had the highest percentage of germination and normal seedlings. In a controlled deterioration test, the sub-sample with the lowest chlorophyll fluorescence signal had slightly lower germination and normal seedling percentages than non-controlled deteriorated seeds, whereas the seeds with highest chlorophyll fluorescence signals had much lower germination and normal seedlings percentages. The advantages of the chlorophyll fluorescence method to determine seed maturity and quality include its high sensitivity and fully non-destructive nature and the high speed at which the fluorescence is generated and measured.

Using the equipment JS 2001 seed sorter, it was possible to remove seeds with high chlorophyll fluorescence and to improve seed lot quality (Jalink et al., 1998; Dell'Aquila et al., 2002; Konstantinova et al., 2002; Kwong et al., 2004). The present research work had the objective of evaluating the use of the chlorophyll fluorescence technique in sorting green seeds from soybean seed lots and its effects on seed quality.

\section{MATERIAL AND METHODS}

\section{Seed samples}

Five seed samples of soybean of the TMG 113 RR cultivar with $0 \%$ (sample 1), $5 \%$ (sample 2 ), $10 \%$ (sample 3), $15 \%$ (sample 4), and $20 \%$ (sample 5) visually evaluated green seeds, were used in this research. The seed samples were provided by "Sementes Adriana", Rondonopolis, MT, Brazil. The seeds of the five samples were similar in size (round hole screen of $6 \mathrm{~mm}$ ).

\section{Chlorophyll fluorescence measurement and sorting}

The equipment JS 2001 Seed Sorter was used for measuring and sorting the chlorophyll fluorescence of the seeds. This equipment was described by Jalink et al. (1998) and is depicted in Figure 1. The light of the LED-lamp
(Hewlett Packard HLMP-8150), which is controlled by a LED power supply (Loep, The Netherlands), is passed through an interference of $656 \mathrm{~nm}$ (Edmund Scientific, USA). The beam splitter reflects about half of the intensity of the LED light towards the lens, which focuses the light onto the seed. A part of the chlorophyll fluorescence is captured by the same lens and about $50 \%$ of the light is directed towards the 730 $\mathrm{nm}$ filter (Edmund Scientific) and photodiode (PIN-10DP, UDT Sensors, USA). The beam splitter was used for easy alignment of the two optical light paths: the excitation light of the LED and the fluorescence of the chlorophyll. With the combination of two interference filters of 656 and $730 \mathrm{~nm}$, the background signal of the system due to stray light of the LED was suppressed to a current of about 1 pico ampere (pA), which was low compared to the average fluorescence signal of $12 \mathrm{pA}$ of the seed lot. A lock-in amplifier (Stanford Research SR 830, USA) was used for sensitive detection of the chlorophyll fluorescence, which modulated the LED light at $77 \mathrm{~Hz}$ and converted the alternating current of the photodiode into a signal that was proportional to the intensity of the chlorophyll fluorescence. The use of a lock-in amplifier had the additional benefit that due to the modulation technique the measurement could be performed under normal room light conditions. The experimental conditions that predominantly determine the magnitude of the chlorophyll fluorescence signal are the spectral distribution and intensity of the excitation light (Nobel, 1970), the surface area of the seed that is illuminated by the light, the structure of the seed coat, the spectral sensitivity of the filter or photodiode combination and the solid angle of the lens system. The solid angle is determined by the distance between the seed and the lens, and the lens diameter.

One thousand seeds of each sample were individually measured with the objective of characterizing the seed samples chlorophyll fluorescence signal distribution. After that, each sample was sorted into two fractions, one with low and the other with high chlorophyll fluorescence seeds, using the sorting level of $1352 \mathrm{pA}$. Finally, one thousand seeds of each of the obtained fractions were measured to characterize the low and the high chlorophyll fluorescence fractions.

\section{Treatments}

The treatments consisted of the control (original sample, without sorting), the low chlorophyll fluorescence seed fraction with signal lower than $1352 \mathrm{pA}$ and the high chlorophyll fluorescence seed fraction with signal higher than $1352 \mathrm{pA}$. 


\section{Germination test}

For each treatment, germination of four replications with 50 seeds each was tested in moist pleated paper at 25 ${ }^{\circ} \mathrm{C}$. The normal and abnormal seedlings and the dead seeds were visually inspected daily, but only the normal seedlings were taken out of the substrate daily, and the abnormal seedlings and the dead seeds remained in the substrate until the final count, made seven days after sowing (Jalink et al., 1998). The germination rate $\left(\mathrm{T}_{50}\right.$, number of days to reach $50 \%$ of maximum germination) was determined simultaneously with the germination test to evaluate the seed vigor (Jalink et al., 1998).

\section{Controlled deterioration test}

This test was performed according to procedures proposed by Krzyzanowski et al. (2001). Seed moisture content was conditioned to $24.4 \%$ and seeds were placed in sealed aluminum bags and artificially aged for 48 hours at 42 ${ }^{\circ} \mathrm{C}$ in an oven. The seeds were then placed for germinating as previously described.

\section{Statistical analysis}

A randomized complete block design was used with four replications for each sample. The normal and abnormal seedlings and the dead seeds of the germination and controlled deterioration tests, and the germination rate $\left(\mathrm{T}_{50}\right)$ were calculated with the software SeedCalculator, version 3.0 (Jalink and van der Schoor, 2002). The data were statistically analyzed using the Student's t-test (level of significance: $\alpha=0.05$ ).

\section{RESULTS AND DISCUSSION}

\section{Chlorophyll fluorescence before and after sorting}

The chlorophyll fluorescence signals of the non-sorted seeds (control) and sorted seeds (low and high chlorophyll fluorescence) for each seed sample are reported in Table 1. Before sorting, samples 1 and 2 presented values of chlorophyll fluorescence signals lower than $800 \mathrm{pA}$, sample 3 stayed in an intermediated position, with $1069.3 \mathrm{pA}$, while samples 4 and 5 presented values higher than 1300 pA. The mentioned values were in accordance with the visual screening of the seed samples, as the samples 1 and 2 presented $0 \%$ and $5 \%$ of green seeds, respectively, while the others samples presented values equal to or higher than $10 \%$ of green seeds. After sorting, great differences were observed between the low and the high chlorophyll fluorescence fractions for all seed samples, even for sample 1 which, upon visual evaluation had $0 \%$ of green seeds. Based on these results it was understood that the equipment used in this study presents a high sensitivity to determine chlorophyll fluorescence in seed samples, as previously reported by Jalink et al. (1998). Percentages of the seeds for the fraction with low chlorophyll fluorescence decreased as the chlorophyll fluorescence signal of the control increased and it also increased as the chlorophyll fluorescence signal of the control increased.

TABLE 1. Average chlorophyll fluorescence (pA) of the control and of the low chlorophyll fluorescence (Low CF) and high chlorophyll fluorescence (High CF) fractions of soybean seeds of the TMG 113 RR cultivar, after sorting the seeds with the JS 2001 Seed Sorter equipment.

\begin{tabular}{cccc}
\hline Sample No. / Green Seed (\%) & Control & Low CF & High CF \\
\hline 1 / 0 & 703.8 & $634.0(92.2 \%)^{1}$ & $1403.3(7.8 \%)$ \\
2 / 5 & 777.7 & $609.5(90.2 \%)$ & $2133.8(9.8 \%)$ \\
3 / 10 & 1069.3 & $733.1(86.2 \%)$ & $2897.1(13.8 \%)$ \\
4 / 15 & 1354.2 & $1086.2(86.8 \%)$ & $2811.4(13.2 \%)$ \\
$5 / 20$ & 1376.3 & $1064.4(83.1 \%)$ & $2556.7(16.9 \%)$
\end{tabular}

${ }^{1}$ The values between parentheses are the percentages of each fraction found in each lot.

\section{Effects of seed sorting by chlorophyll fluorescence on germination}

The germination performance of seeds from the control and the low chlorophyll fluorescence treatments was similar in almost all aspects for the five samples (Table 2), with the exception that the low chlorophyll fluorescence treatment presented lower percentages of dead seeds for the in samples 1,3 and 4 . On the other, hand the 
germination performance of seeds from the low chlorophyll fluorescence and control, for the samples 2 to 5 , was better than that from seeds with high chlorophyll fluorescence, showing, clearly, that green seeds are of low quality and contribute to increasing the percentage of dead seeds in the samples. Additionally, it was verified that the time for the seeds to reach $50 \%$ of maximum germination $\left(\mathrm{T}_{50}\right)$ was shorter for seeds with low chlorophyll fluorescence than those with high chlorophyll fluorescence for the samples that presented visually detected green seeds (samples 2 to 5). This fact leads to the statement that seeds with low chlorophyll fluorescence present higher vigor than the ones with high fluorescence. Jalink et al. (1998), working with Brassica oleracea, also observed higher quality in seeds with low chlorophyll fluorescence compared to those with high chlorophyll fluorescence.

TABLE 2. Normal seedlings (NS), abnormal seedlings (AS), dead seeds (DS) and time to reach $50 \%$ of maximum germination $\left(T_{50}\right)$, observed in the germination test of soybean seeds of the TMG 113 RR cultivar with different levels of green seeds and chlorophyll fluorescence (CF).

\begin{tabular}{cccccc}
\hline $\begin{array}{c}\text { Sample No. / } \\
\text { Green Seed (\%) }\end{array}$ & Treatment & $\begin{array}{c}\text { NS } \\
(\%)\end{array}$ & $\begin{array}{c}\text { AS } \\
(\%)\end{array}$ & $\begin{array}{c}\text { DS } \\
(\%)\end{array}$ & $\begin{array}{c}\mathrm{T}_{50} \\
(\text { days })\end{array}$ \\
\hline \multirow{3}{*}{$1 / 0$} & Control & $89.5 \mathrm{ab}^{1}$ & $5.0 \mathrm{a}$ & $5.5 \mathrm{~b}$ & $2.79 \mathrm{a}$ \\
& Low CF & $91.5 \mathrm{a}$ & $6.0 \mathrm{a}$ & $2.5 \mathrm{c}$ & $2.69 \mathrm{a}$ \\
& High CF & $80.0 \mathrm{~b}$ & $11.0 \mathrm{a}$ & $9.0 \mathrm{a}$ & $2.71 \mathrm{a}$ \\
\hline \multirow{3}{*}{$2 / 5$} & Control & $88.0 \mathrm{a}$ & $7.0 \mathrm{a}$ & $5.0 \mathrm{a}$ & $2.65 \mathrm{ab}$ \\
& Low CF & $92.0 \mathrm{a}$ & $4.0 \mathrm{a}$ & $4.0 \mathrm{a}$ & $2.49 \mathrm{~b}$ \\
& High CF & $75.0 \mathrm{~b}$ & $16.0 \mathrm{~b}$ & $9.0 \mathrm{a}$ & $2.83 \mathrm{a}$ \\
\hline \multirow{3}{*}{$3 / 10$} & Control & $78.5 \mathrm{a}$ & $12.0 \mathrm{a}$ & $9.5 \mathrm{~b}$ & $2.58 \mathrm{ab}$ \\
& Low CF & $89.5 \mathrm{a}$ & $8.0 \mathrm{a}$ & $2.5 \mathrm{c}$ & $2.44 \mathrm{~b}$ \\
& High CF & $59.0 \mathrm{~b}$ & $17.5 \mathrm{a}$ & $23.5 \mathrm{a}$ & $2.85 \mathrm{a}$ \\
\hline \multirow{3}{*}{$4 / 15$} & Control & $81.5 \mathrm{a}$ & $13.0 \mathrm{a}$ & $5.0 \mathrm{~b}$ & $2.44 \mathrm{~b}$ \\
& Low CF & $90.0 \mathrm{a}$ & $8.5 \mathrm{a}$ & $1.5 \mathrm{c}$ & $2.44 \mathrm{~b}$ \\
& High CF & $69.5 \mathrm{~b}$ & $17.5 \mathrm{~b}$ & $13.0 \mathrm{a}$ & $2.68 \mathrm{a}$ \\
\hline \multirow{2}{*}{$5 / 20$} & Control & $81.0 \mathrm{a}$ & $14.0 \mathrm{a}$ & $5.0 \mathrm{~b}$ & $2.52 \mathrm{~b}$ \\
& Low CF & $86.5 \mathrm{a}$ & $12.0 \mathrm{a}$ & $1.5 \mathrm{~b}$ & $2.45 \mathrm{~b}$ \\
& High CF & $60.5 \mathrm{~b}$ & $18.0 \mathrm{a}$ & $21.0 \mathrm{a}$ & $3.00 \mathrm{a}$ \\
\hline
\end{tabular}

${ }^{1}$ Means followed by the same letter in each column for each sample do not differ statistically from each other according to the Student's t-test (level of significance: $\alpha \leq 0.05)$.

\section{Effects of controlled deterioration on seeds sorted by chlorophyll fluorescence}

The effects of chlorophyll fluorescence sorting on seed quality were shown more clearly by the controlled deterioration test (Table 3). The controlled deterioration test had a higher effect on the seed performance of the high chlorophyll fluorescence treatment. The percentage of normal seedlings was higher for the low chlorophyll fluorescence treatment in relation to the control and high chlorophyll treatments for samples 2 to 5 and higher than for the high chlorophyll fluorescence treatment in sample 1 . This situation was especially clear when dead seeds are observed in high chlorophyll fluorescence in relation to low chlorophyll fluorescence treatments: this parameter increased from $9.0 \%$ to $21.0 \%$ for sample 1 , from $4.5 \%$ to $43.0 \%$ for sample 2 , from $13.0 \%$ to $72.0 \%$ for sample 3 , from $14,5 \%$ to $61.0 \%$ for sample 4 and from $16.0 \%$ to $67.0 \%$ for sample 5 . The control also presented higher performance in relation to high chlorophyll fluorescence treatment, for all samples. Jalink et al. (1998) also observed that the effects of chlorophyll fluorescence sorting on seed quality of Brassica oleracea were more evident in a controlled deterioration test. 
TABLE 3. Normal seedlings (NS), abnormal seedlings (AS) and dead seeds (DS) observed after the controlled deterioration test of soybean seeds of the TMG 113 RR cultivar with different levels of green seeds and chlorophyll fluorescence (CF).

\begin{tabular}{ccccc}
\hline $\begin{array}{c}\text { Sample No. / } \\
\text { Green Seed (\%) }\end{array}$ & Treatment & NS & AS & $\begin{array}{c}\text { DS } \\
(\%)\end{array}$ \\
\hline \multirow{3}{*}{$1 / 0$} & Control & $72.0 \mathrm{a}$ & $15.0 \mathrm{~b}$ & $13.0 \mathrm{ab}$ \\
& Low CF & $77.5 \mathrm{a}$ & $13.5 \mathrm{~b}$ & $9.0 \mathrm{~b}$ \\
& High CF & $51.5 \mathrm{~b}$ & $27.5 \mathrm{a}$ & $13.0 \mathrm{~b}$ \\
\hline \multirow{2}{*}{$2 / 5$} & Control & $78.5 \mathrm{~b}$ & $8.5 \mathrm{~b}$ & $4.5 \mathrm{c}$ \\
& Low CF & $85.5 \mathrm{a}$ & $10.0 \mathrm{~b}$ & $43.0 \mathrm{a}$ \\
\hline \multirow{3}{*}{$3 / 10$} & High CF & $41.0 \mathrm{c}$ & $16.0 \mathrm{a}$ & $33.0 \mathrm{~b}$ \\
& Control & $52.5 \mathrm{~b}$ & $14.5 \mathrm{a}$ & $13.0 \mathrm{c}$ \\
& Low CF & $72.5 \mathrm{a}$ & $14.5 \mathrm{a}$ & $72.0 \mathrm{a}$ \\
\hline \multirow{3}{*}{$4 / 15$} & High CF & $12.5 \mathrm{c}$ & $15.5 \mathrm{a}$ & $28.5 \mathrm{~b}$ \\
& Control & $44.5 \mathrm{~b}$ & $27.0 \mathrm{a}$ & $14.5 \mathrm{c}$ \\
& Low CF & $67.5 \mathrm{a}$ & $18.0 \mathrm{~b}$ & $61.0 \mathrm{a}$ \\
\hline \multirow{2}{*}{$5 / 20$} & High CF & $23.0 \mathrm{c}$ & $16.0 \mathrm{~b}$ & $33.0 \mathrm{~b}$ \\
& Control & $45.5 \mathrm{~b}$ & $21.5 \mathrm{a}$ & $16.0 \mathrm{c}$ \\
& Low CF & $60.5 \mathrm{a}$ & $23.5 \mathrm{a}$ & $67.0 \mathrm{a}$ \\
\hline
\end{tabular}

${ }^{1}$ Means followed by the same letter in each column for each sample do not differ statistically from each other according to the Student's t-test (level of significance: $\alpha \leq 0.05)$.

The controlled deterioration test is an appropriate test to evaluate the storage potential of soybean seed lots, as soybean seeds are highly susceptible to loss of quality during storage. Certainly the loss of quality by low quality seeds during storage has a faster rate than that shown by high quality seeds. Therefore, the results herein reported are an indication that the removal of green seeds based on the results of the chlorophyll fluorescence test and making use of a machine specifically designed for this purpose may significantly improve soybean seed quality and thus allow longer storage periods.

With the results obtained in this research, it was possible to conclude that green seeds have a negative effect on soybean quality as also reported by Costa et al. (2001), Bohner (2003), Medina et al. (1997), Pupim et al. (2005), Padua et al. (2007) and Zorato et al. (2007). It was also concluded that green seeds present high chlorophyll fluorescence and it is possible to improve soybean seed quality by removing these seeds using chlorophyll fluorescence sorting, as Jalink et al. (1998) did with Brassica oleracea seeds.

\section{CONCLUSIONS}

Green seeds present high chlorophyll fluorescence and have a negative effect on soybean seed quality. It is possible to improve soybean seed quality by removing these seeds using the chlorophyll fluorescence sorting equipment.

\section{ACKNOWLEDGEMENTS}

The authors wish to thank "Sementes Adriana" for providing the seeds, "Conselho Nacional de Desenvolvimento Científico e Tecnológico (CNPq)" for the financial support and Prof. Dr. Nelson Moreira de Carvalho for his valuable comments on the manuscript.

\section{REFERENCES}

ABRASEM. Associação Brasileira de Sementes e Mudas. Estatística da produção. Anuário ABRASEM 2009, Pelotas: Editora Becker \& Peske, p.32, 2009. 
BOHNER, H. Green soybeans. Ministry of Agriculture, Food and Rural Affairs, Ontario, 2003. Available at: http//:www. omafra.gov.on.ca/english/crops/facts/ greenbeans02.htm. Accessed at: 02 Oct. 2006.

CONAB. Companhia Nacional de Abastecimento. Acompanhamento de safra brasileira: grãos, décimo segundo levantamento. Available at: http//:www.conab. gov.br/conabweb/. Accessed at: 2 Sept. 2009.

COSTA, N.P.; FRANÇA-NETO, J.B.; PEREIRA, J.E.; MESQUITA, C.M.; KRZYZANOWSKI, F.C.; HENNING, A.A. Efeito de sementes verdes na qualidade fisiológica de sementes de soja. Revista Brasileira de Sementes, v.23, n.1, p.102-107, 2001.

DELL'AQUILA, A.R.; van der SCHOOR, R.; JALINK, H. (2002). Application of chlorophyll fluorescence in sorting controlled deteriorated white cabbage (Brassica oleracea L.) seeds. Seed Science and Technology, v.30, p.689-695, 2002.

DORNBOS, D.L.; MULLEN, R.E. Influence of stress during soybean seed fill on seed weight, germination and vigor. Crop Science, v.29, p.476-480, 1991.

FRANÇA-NETO, J.B.; KRZYZANOWSKI, F.C.; BRUMATTI, P.; PADUA, G.; COSTA, N.P. Removal of green seeds of soybean from seed lots by processing. In: INTERNATIONAL SEED TESTING ASSOCIATION CONGRESS, 28., Foz do Iguaçu, 2007. Seed Symposium Abstracts. Foz do Iguaçu: 2007. p.12.

FRANÇA-NETO, J.B.; PADUA, G.P.; CARVALHO, M.L.M.; COSTA, O.; BRUMATTI, P.S.R.; KRZYZANOWSKI, F.C.; COSTA, N.P.; HENNING, A.A.; SANCHES, D.P. Semente esverdeada de soja e sua qualidade fisiológica. Londrina: Embrapa Soja, 2005. (Circular Técnica, 38).

JALINK, H.; van der SCHOOR, R.; FRANDAS, A.; van PIJLEN, J.G. Chlorophyll fluorescence of Brassica oleracea seeds as a non-destructive marker for seed maturity and seed performance. Seed Science Research, v.8, p.437-443, 1998.

JALINK, H.; van der SCHOOR, R. SeedCalcultor 3.0, User's Guide. Wageningen: Plant Research International B.V., 2002. 26p.

KRZYZANOWSKI, F.C.; WEST, S.H.; FRANÇA-NETO,
J.B. O teste de deterioração controlada para a avaliação da qualidade fisiológica da semente de soja. Informativo ABRATES, v.11, n.2, p.185, 2001.

KONSTANTINOVA, P.; van der SCHOOR, R.; van den BULK, R.W.; JALINK, H. Chlorophyll fluorescence sorting as a method for improvement of barley (Hordeum vulgare L.) seed health and germination. Seed Science and Technology, v.30, p.411-421, 2002.

KWONG，F.Y.; SELLMAN， R.L.; JALINK，H.; van der SCHOOR, R. Flower seed cleaning and grading. In: McDONALD, M.B.; KWONG, F.Y. (Ed.) Flower Seeds: Biology and Technology. UK: Cabi Publishing, 2004. p.225-247.

MARCOS-FILHO, J. Fisiologia de sementes de plantas cultivadas. Piracicaba: FEALQ, 2005. 495p.

McGREGOR, D.I. Influence of environment and genotype on rape seed/canola seed chlorophyll content. Seed Science and Technology, v.19, p.107-116, 1991.

MEDINA, P.F.; LAGO, A.A.; RAZERA, L.F.; MAEDA, J.A. Composição física e qualidade fisiológica de lotes de sementes de soja com incidência de sementes esverdeadas. Informativo ABRATES, v.7, n.1/2, p. 36, 1997.

NOBEL, P.S. Plant cell physiology: a physiological approach. San Francisco: W.H. Freeman, 1970. 267p.

PADUA, G.P.; FRANÇA-NETO, J.B.; CARVALHO, M.L.M.; COSTA, O.; KRZYZANOWSKI, F.C.; COSTA, N.P. Tolerance level of green seed in soybean seed lots after storage. Revista Brasileira de Sementes, v.29, n.3, p.112120. 2007.

PUPIM. T.L.; CARVALHO, M.L.M.; PADUA, G.P.; NERY, M.C.; FRANÇA-NETO, J.B. Ocorrência de sementes verdes e qualidade fisiológica de sementes de soja. Informativo ABRATES, v.15, p.238, 2005.

ZORATO, M.F.; PESKE, S.T.; TAKEDA, C.; FRANÇANETO, J.B. Presença de sementes esverdeadas em soja e seus efeitos sobre seu potencial fisiológico. Revista Brasileira de Sementes, v.29, n.1, p.11-19, 2007.

ZORATO, M. F.; WATANABE, P.A.T. Soja esverdeada: a degradação parcial da clorofila. In: SUZUKI, S.; YUYAMA, M.M.; CAMACHO, S.A. Boletim de Pesquisa de Soja 2006. Rondonópolis: Fundação MT, 2006. p.229232. 